Article

\title{
Relevance of Social, Economic, and Environmental Impacts on Residents' Satisfaction with the Public Administration of Tourism
}

\author{
María-Elena Sánchez del Río-Vázquez® ${ }^{\circledR}$ Carlos J. Rodríguez-Rad $®$ and \\ María-Ángeles Revilla-Camacho * (1) \\ Business Administration and Marketing, Universidad de Sevilla, 41004 Sevilla, Spain; \\ edelrio@us.es (M.-E.S.d.R.-V.); crodri@us.es (C.J.R.-R.) \\ * Correspondence: arevilla@us.es
}

Received: 28 October 2019; Accepted: 10 November 2019; Published: 13 November 2019

\begin{abstract}
Those in charge of tourism destinations face the need to create tourism development models compatible with the essence of the localities that they manage. These models have to be sustainable, both environmentally and socially, and also must become drivers of the local economy. However, tourists also generate negative impacts in the locality which, when they are perceived by the residents, can give rise to a rejection of visitors. Hence, improving the tourism management is necessary. This is why to know the residents' perceptions about the impacts of tourism is essential. Moreover, measuring the impact effects on their satisfaction with the public administration of the destination can be of great usefulness. This study falls into this research line, as it proposes a model to measure these impacts and their effect on satisfaction. To do so, an empirical study is performed among residents in the city of Seville (southern Spain, one of the most visited destinations in the world), based on subjective economic, social, and environmental indicators. The results show that the citizens value three types of impacts, the social impact coming after the economic impact as to its influence on their satisfaction with the administration. Based on this, we postulate that the efforts made to attract events to the city, or to improve connections to access a broader market, must be approached as public procurements in which selection criteria that are compatible with the destination's positioning and strategy prevail. Social and environmental criteria should be considered among these criteria.
\end{abstract}

Keywords: social impact; environmental impact; economic impact; tourism management; perceived value

\section{Introduction}

The consideration of consumption as a driver of the economy has for years fostered a lifestyle, which gives rise to serious social imbalances and the threat of a scarcity of energy, water, and other resources. This situation has promoted, at an international level, the development of an approach of public procurement [1-3], which integrates different impacts: Its environmental impact, considering, for example, greenhouse gas emissions (GHG) or the consumption of water and energy; its social impact, through the presence of small and medium-sized enterprises (SMEs) in the contracting or the inclusion of employees at risk of exclusion, among others; its economic impact, mainly through savings generated, such as the cost of the lifecycle; and its impact regarding innovation which, as such, is at a very early stage, but has great potential and relevance. Consequently, since 2001 the European Commission has developed different measures to encourage environmental and socially sustainable and innovative public contracting, but we are still at an incipient stage: The price, ahead of the technical quality of the offer, is still considered the main criterion of choice in public tenders [4]. 
In this line, [5] conclude in their study with experts in Public Procurement that there is a need to train the personnel involved in the process of public procurement to achieve a view of value and not only of price (economic criterion), suggesting even the development of campaigns which make citizens knowledgeable about the use of environmental, social, and economically sustainable criteria in public tenders. The experts also call for objective accounting models of these factors, as well as the price factor and the incorporation of new criteria to identify and quantify the social value generated.

It is therefore fundamental to know the social value and the level of sustainability of the public tender from its multiple impacts, mainly environmental, social, and economic [6,7]. It is fundamental because Public Procurement promotes responsible behaviors. Hence, it has the capacity to facilitate changes in production and consumption models that are not sustainable $[2,8]$. The initiatives regarding sustainable public procurement developed, both nationally and internationally by the European Union, United Nations Environment Program (UNEP), the Organization for Economic Cooperation and Development (OECD), or others, come to defend this exemplary capacity of public procurement. It is also essential to be aware of the citizens' perception concerning the different impacts of Public Procurement. For both aims, it is necessary to dispose of information related to each type of impact in each offer. We can turn to the use of indicators to achieve this. These are quantitative instruments fundamental in management and territorial or sectoral planning for their capacity of prevention, as they can alert about possible negative impacts. They must, therefore, "generate information, be methodologically consistent, scientifically valid and easy to apply and communicate" [9] (p. 431).

For its part, tourism was one of the first fields which became aware of the importance of sustainability and due to its continued concern for sustainability it is ahead of many other industries and has made a great leap forward to demonstrate the importance which it gives to it [10]. On the other hand, tourism is the third largest sector of international trade with $10.4 \%$ of the GDP and is responsible for 313 million jobs worldwide, according to the joint communique "Tourism, Trade and the WTO", of 8 October 2018, of the The World Tourism Organization (UNWTO), the World Trade Organization (WTO), the World Travel \& Tourism Council (WTTC), and the International Trade Centre (ITC) [11]. Tourism has also been included in the Final Document of Rio + 20, as a sector capable of significantly contributing to the three dimensions of sustainable development. Due to all of this, it must be well administrated for it to benefit local communities and the natural and cultural environments in which it is developed, as is reflected in the Guidebook "Sustainable Tourism for Development" which was produced by WTO in 2011, with the financing of the European Commission Directorate-General Development and Cooperation, and was published in 2013 [12].

Hence, the importance of an appropriate Public and Sustainable Administration of Tourism and which, therefore, requires the use of tourism indicators that reflect the social value or the level of sustainability of each offer and procurement decision or contracting. Therefore, diverse studies have tried to respond to the suitability of counting on an operative framework which helps to achieve a sustainable public administration. This is for the public destination managers to have information at their disposal relative to the scope of the objectives of sustainability proposed when they require it and in a systematic manner.

Consequently, at the global level, a relevant increase of the initiatives with regard to indicators has been generated, in such a way that governments, academic institutions, private firms, and the communities themselves have carried out research into the matter [13]. However, among the difficulties which researchers face is that there does not exist a scientific agreement regarding which are the indicators to use [13]. Nor is there an agreement among experts and scientists regarding the number of indictors of each dimension or impact. This is linked to the lack of consensus which the very concept of sustainable development also reflects $[9,14,15]$. Nevertheless, these difficulties must not halt the interest in going deeply into the knowledge and the assessment of the tourism indictors given that, as Moreno et al. [16] assert, if a system of effective control in tourism administration is not implemented, we may find ourselves with a process of spontaneous and unsustainable development. 
On the other hand, though the concept of sustainability comes from the environmental field [17], there does seem to be a greater consensus concerning the integral study of sustainability, the economic and socio-cultural impacts, as well as the environmental impact being mainly considered as those most relevant in tourism [9,15]. In this line, the European Commission offered in 2013 the "European Tourism Indicators System (ETIS)" as a tool, of voluntary use, so that destinations may measure and control the results of their tourism administration in terms of sustainability, using a common comparable approach. After a review process, the European Commission published the current 2016 edition in which it proposes a system of 43 basic indicators which aids controlling the essential aspects of sustainability, and other optional indicators, as an open list that helps the system to adapt itself according to the destination's specific needs or category. All these are subdivided into four categories: Administration of Destinations, Social and cultural influence, Economic value, and Environmental impact [18].

Nevertheless, most of the research has centered on objective indicators, losing sight of the view of the destination's tourists and residents who are the main agents involved in tourism. In addition, it is especially important to know the perception of the citizens of the Public Tourism Administration as this will reveal their being aware or not of the effort of this administration in matters of sustainability, as well as their assessment, which will influence their level of satisfaction with the public administration of tourism. Therefore, it is relevant to incorporate subjective indicators into the studies of tourism sustainability. This is reflected by the WTO, which states that sustainable tourism is "Tourism that takes full account of its current and future economic, social and environmental impacts, addressing the needs of visitors, the industry, the environment and lost communities" [19].

In this line, Sancho and García [20] state that, in the evaluation of tourism administration, too much importance has been given to easily quantifiable indicators; that is to say, the aims of investment, inflation, etc. However, these indicators must be complemented with indicators that are more difficult to quantify, in other words subjective, to discover the perceptions and satisfaction of the local population and of the tourists as internal and external customers, respectively, of the tourism administration. This is even more important given that the results of both types of indicators may not coincide.

Specifically, the support of the residents of the destination is essential, as a hospitable local population is a critical factor for the tourism development; the residents influence the satisfaction of the tourist [21]. Hence, if the planners wish to be successful in any tourism project, it is essential to identify and understand the factors which influence the support of the host community [22].

In line with what has been stated, the WTO [13] made it known that the residents' assessment of the different impacts of tourism and their satisfaction are fundamental for the sustainability of tourism. In extreme cases, the hostility of the local population has alienated tourists. Therefore, it suggests the use of questionnaires targeting the residents which are repeated annually to compare the results of two or more similar communities of the same destination and carry out time comparisons. These questionnaires are of great importance as the host community's groups of individuals may have different opinions about what is positive or negative for them. Consequently, these subjective indicators are basic indicators for the Public Tourism Administration as they serve as an alert. That is to say, they are a key tool for control in this administration, as they permit the planning of corrective measures when a negative effect is identified. Moreover, they reflect the citizens' assessment of the administration, which is important as the residents are its internal customers.

Lastly, although much of the literature shows studies with different indicators, these used to focus on only one of its impacts [23], and mainly on the environmental impact, because of the origin of the term "sustainable development" and the environmental degradation and excessive consumption of natural resources as consequences of tourism $[9,24]$. Another reason can also be found in the lack of consensus on the meaning of "sustainability" $[15,25]$. However, in recent times tourism has caused other socio-economic problems, so studies on the subject have evolved in recent years [24]. Due to the growing consensus for the need to include social value in public tender [5], it is necessary to include socio-cultural indicators in tourism assessment. As the WTO again specifically indicates [13], in all the 
forms of tourism and all kinds of destinations, an appropriate balance must be found between the three main dimensions already commented on to attain long-term sustainability. Some studies also include the institutional, political, technological dimensions, and others that are specific to the concrete approach that they study $[9,15,24]$.

The aim of our research has been to analyze the perceptions of environmental, economic, and social impacts of tourism by residents of the destination town, their satisfaction with the Public Administration of Tourism and the cause-effect relationship between them. Assessing the responses from 447 residents in the city of Seville (Spain) and due to the importance of resident's behavior as an integral part of the tourism product, we have attempted to meet a further objective that is to support Public Administration in Tourism Planning.

The paper attempts to answer a series of questions expressed in previous researches:

1. Tourism may become a threat if it is not managed, and satisfaction of the needs of tourists and current and future residents should be considered key aspects in strategic tourism planning $[12,26]$. Hence, tools that provide information on what current activities are unsustainable and to what extent are widely recognized [23,24];

2. Tourist surveys are an important source of useful information (Moore et al. 2007), but it is strange that tourist satisfaction measures are more numerous than satisfaction of the host [27]. Moreover, the broad consensus on the idea that input of residents should be integrated into any tourism planning process is important [22,28]. Indifference or hostility from residents could make tourists move away [21,29];

3. Resident's attitude towards tourism and their perception on tourism impacts have been widely treated $[28,30]$. However, literature reveals that many studies seem to use attitude when in fact they measure perception; therefore, few scholars have recommended a careful use of the terms [31]. Satisfaction may also have been measured as perception of tourism sustainability or attitude towards tourism;

4. Understanding the antecedents of residents' support to tourism is crucial for policy makers [32]. Hence, the lack of explanatory research limits the understanding of resident responses towards tourism [31]. In this line, applying methodologies that allow to measure relationships among host satisfaction, tourism impact perception, personal benefits from tourism, attitude towards tourism, etc., are recommendable [33,34].

\section{Theoretical Foundations and Development of Hypotheses}

Next, we analyze each impact or dimension of sustainability and, specifically, we mention some of the indicators which the literature has considered appropriate for the tourism field. However, we must make two important remarks. Firstly, the effects of tourism on the destination place are interlinked in such a way that they generate synergies. Secondly, the lists of indicators offered by different sources must be taken as open and adaptable lists so that in future research new indicators can be included in order to adjust them to each destination's peculiarities. We also analyze the concept Residents' Satisfaction with tourism, thus taking into consideration, along with the tourists, one of the main agents of the tourism experience, the destination's residents.

\subsection{Economic Impact}

The concept "Circular Economy" arises supporting the sustainability of the planet. This advocates an economic development which respects the environmental limits. By transforming waste into new resources, it achieves a greater efficiency, also favoring the local economy [4]. On the other hand, tourism has become a key driver of the socio-economic progress in countries worldwide and hence the importance of its administration. The sustainability of the destination cannot be guaranteed without a specific administration, which generates economic performance [16]. We also point out the synergy between impacts, so that the economic development frequently involves cultural changes, 
which accompany the tourism development. Hence, at times the economic impacts are evaluated as socio-cultural impacts [13] and therefore the economic and cultural indicators in the different research studies do not coincide.

The ETIS and the WTO are references in the development of tourism impact indicators, though the latter places greater emphasis on the appropriateness of supplementing objective indicators with subjective indicators. Thus, for example, among the objective indicators we find the number of overnight stays, the relative contribution of tourism to the economy of the tourism destination in question (percentage of the GDP), the daily expenditure per tourist who stays overnight, the occupancy rate in commercial lodgings, the residents employed in the tourism sector, seasonal employment, tourism businesses, business permits and licenses, revenues generated, etc. [13,18]. Furthermore, the WTO [13] proposes knowing the residents' perception of the economic impact through a periodic questionnaire with subjective indicators, such as the assessment of the creation of employment for local residents, for young people in the locality, the price increases of items, among others.

In this line, the research of Sancho and García [20] stands out. This offers a list of both objective and subjective indicators, the latter for the perception of residents and tourists concerning the economic impact of the tourism development in their environment. Focusing on the residents, they offer indicators of perception related with the creation of jobs, the attraction of investment, and the increase of prices, among others. On the other hand, in the environment of rural tourism, the study of Marzo et al. [35] proposes a measurement scale of the residents' perceptions, which is later refined with the following economic indicators: Employment for the community, benefits for the firms involved and for all the community, the improvement of the existing infrastructures and of the quality of life.

\subsection{Environmental Impact}

Among the basic principles of the Global Code of Ethics for Tourism is the maintaining of the destination's environmental quality [36]. For its part, the EU, aiming to foster an efficient use of resources for the development of a Green Economy, defines the term "Green Public Procurement" (GPP) or "Sustainable Public Procurement" (SPP) as " ... a process whereby public authorities seek to procure goods, services and works with a reduced environmental impact throughout their life cycle when compared to goods, services and works with the same primary function that would otherwise be procured." [37] (p. 4). Though only in the more advanced countries of the EU, today one talks about "Circular Procurement" when combining the concepts of a Circular Economy and Green Public Procurement [4]

In this endeavor, Spain passed the Plan of Green Public Procurement (2018-2025) (PGPP), which offers a series of "general environmental procurement, of a voluntary nature, which may be incorporated into the procurement sheets" [8]. Returning to tourism, its administration is key to guarantee the integrity of natural resources typical of the destination; these may, moreover, be the fundamental motive of the visit [16]. Again, the ETIS and the WTO are key in the analysis of its environmental impact from objective indicators relative to the means of transport, the carbon footprint, the participation of tourism firms in programs of mitigation of climate change, waste and waste water, the consumption of water and energy, biodiversity, the local scenery, protected areas, the reproduction of selected species, businesses in energy conservation programs or that apply policies and techniques of energy saving, renewable, recycled resources, etc., $[13,18]$. Subjective indicators are also included, such as the residents' perception of the damage to the environment and the use of natural resources necessary for the residents (fishing, hunting, water, etc.) [13]. The authors in [20,35] propose indicators on the perception of public investment in the environment, the recuperation and promotion of natural species, the amounts of rubbish in the streets, traffic congestion, environmental noise, the worsening of the environment, accessibility to natural areas, conserving natural resources, and increasing the society's ecological awareness, among other matters. 


\subsection{Socio-Cultural Impact}

The Directive 2014/24/UE of public procurement, in its point $n^{\circ} 2$, specifically indicates that it must facilitate "the participation of small and medium-sized enterprises (SMEs) in public procurement, ....... in support of common societal goals" [38] (p. L 94/65). Therefore, public contracts must be dynamizers of good business practices, becoming a judicial tool in public powers to achieve their "fundamental aims and values: social cohesion, redistribution of wealth, equality and justice" [39] (p. 5). In this line, The European Commission in 2011, converted this into Socially Sustainable Public Procurement (SSPP) considering:

"one or more of the following social considerations: employment opportunities, decent work, compliance with social and labour rights, social inclusion (including persons with disabilities), equal opportunities, accessibility design for all, taking account of sustainability criteria, including ethical trade issues (6) and wider voluntary compliance with corporate social responsibility (CSR), while observing the principles enshrined in the Treaty for the European Union (TFEU) and the Procurement Directives" [6] (p. 7).

For its part, the Global Code of Ethics for Tourism supports the improvement of the host community's quality of life, as well as the maintaining of its cultural quality [36], aiming to minimize the negative impacts of tourism on the heritage at the same time as maximizing the benefits for the local population of the destinations [40]. Therefore, the public administration of tourism must protect the cultural resources inherent to the destination, which may be the reason for the tourists' visits. Furthermore, the administration must avoid possible socio-cultural conflicts which may negatively influence the traditional lifestyle, traditions, or local values. This must be done in such a way that it benefits the local population by its involvement in experiential activities, in the creation of new firms in the sector, exploring the possibilities of arts and crafts, etc. [16].

Thus, tourism means "jobs, poverty eradication, gender equality, and the protection and promotion of our natural and cultural heritage" [12] (p. 9).

The ETIS consistently proposes measuring the socio-cultural impact of tourism from indicators relative to the complaints of the tourists to the police and the people employed in tourism, the public transport and places of interest accessible to disabled people and those with specific accessibility needs, the residents satisfied with the impact of tourism on the destination's identity, the events held there and centered on culture, and the traditional heritage, among others [18].

Returning to the synergy of the impacts of tourism, the WTO [13] declares that the socio-cultural effects tend to be mixed, especially those that are economic as they are difficult to measure. On the other hand, the local population at times does not wish to share its culture with tourists and does not understand the interest of tourists in their traditions. Nevertheless, the current globalization favors interaction between cultures, the local population receiving the impact of the cultures of the visitors, and vice versa, thus making isolation complicated. Hence, the increase of the rate of delinquency, the undermining of moral norms, the stimulus of local crafts and culture, etc., are some of the perceptual indicators suggested.

Similarly, later studies, such as those of Sancho and García [20] and Marzo et al. [35], offer subjective indicators for residents, such as the improvement of cultural, educational, and recreational means, the restoration of historic buildings, the recuperating of traditional crafts and local traditions, the influence on the lifestyle and quality of life, the maintaining of the local identity and culture, of social welfare (health, safety, etc.), of public services and infrastructures, etc.

\subsection{Satisfaction with the Public Administration of Tourism}

We now recall that the residents' satisfaction is a basic indicator for the Public Tourism Administration as it serves as a tool in the control of this administration. The public administration and, in the topic which we are addressing, the Public Tourism Administration must seek the satisfaction of its customers and the citizens who reside in the destination are its internal customers. 
Moreover, the local population is capable of influencing the tourism development in its locality as it is the main agent, along with the tourists, which more directly experiences the tourism experience. Therefore, the residents' collaboration in carrying out sustainable tourism policies is essential for the development of the activity and this support depends on the residents' opinions and satisfaction. With this in mind, De Oliveira [41] places emphasis on administrations having to be aware of the link between tourism development and residents' satisfaction and opinion.

On the other hand, the local population's degree of satisfaction depends on the level of impact that the tourism activity can generate [42]. Hence, for example, the interaction between the tourists and the residents, as well as the development of the industry itself can create changes in the local population's quality of life [43], which can influence the residents' satisfaction.

For its part, the WTO [13] suggests two methods for its measurement, one objective through the analysis of the number of complaints presented by the residents to the local authorities and another subjective through a community questionnaire; that is to say, targeting the destination's residents. What is more, it is likewise recommended, for the residents' assessment of the different impacts of tourism, to repeat the analysis annually to compare the results of two or more similar communities of the same destination or to measure the trend of the level of general satisfaction over time.

Though, there exist quite a number of research works on satisfaction with tourism experience, centered on the satisfaction of the tourists. There are very few which deal with the satisfaction of the host. Moreover, the latter are based on the WTO's C6 questionnaire model [13], only offering one 5-point Likert-type question about general satisfaction with tourism, while it has 14 questions about the assessment of the different effects of tourism, two questions about the benefit of tourism for the community and for the residents themselves, and one about the wish for there to be more or less tourism, all also 5-point Likert-type, as well as two open questions for the residents to be able to express their ideas.

Lastly, the researchers have also centered more on the relations between the hosts' perceptions of the sustainability of tourism and their support of it [44]. We do not find studies which address the relation between these perceptions and the residents' satisfaction with the administration of tourism.

Based on these considerations, we propose the following model of relations (see Figure 1):

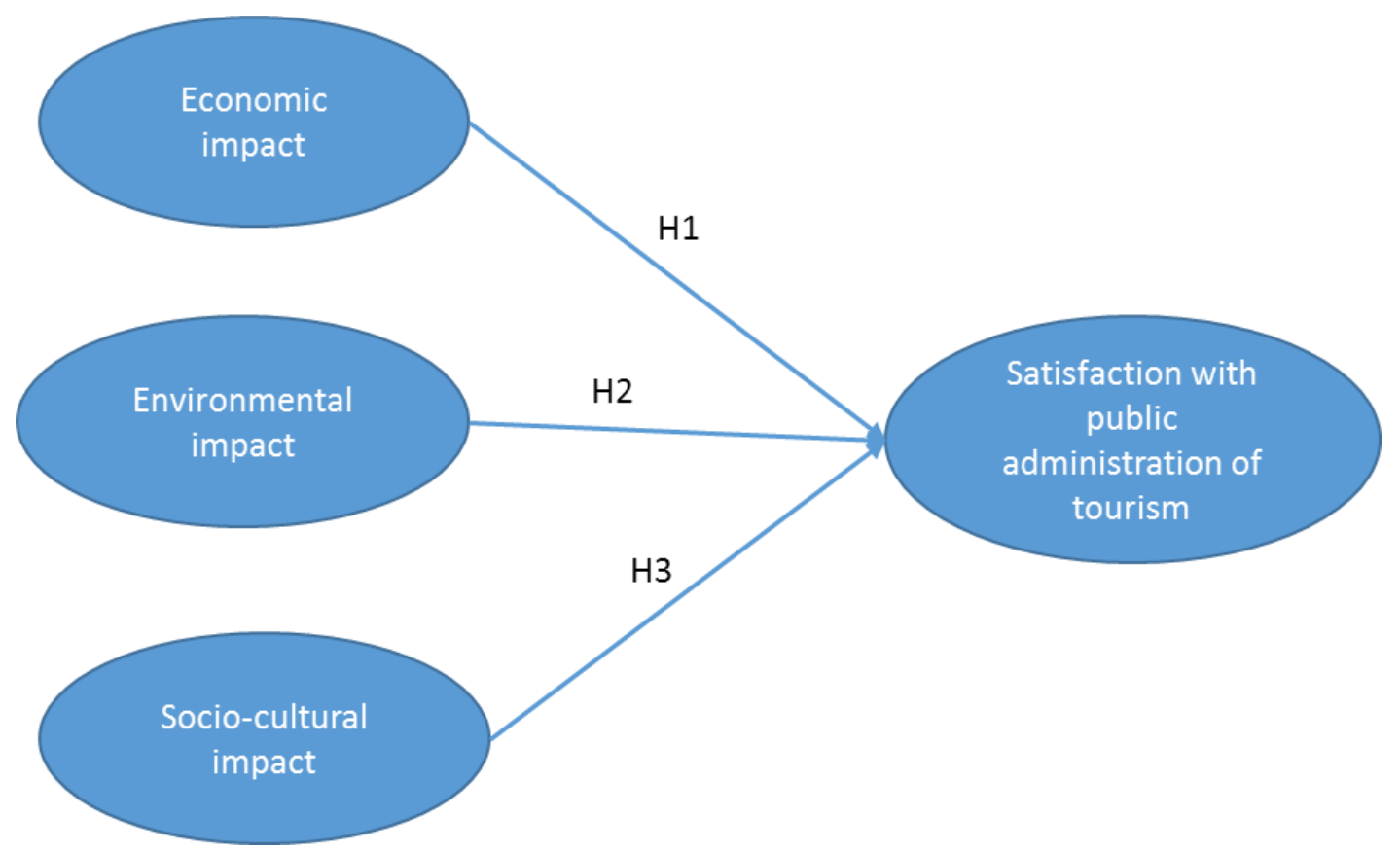

Figure 1. Model proposed. 
H1. A high positive economic impact positively affects satisfaction with the public administration of tourism.

H2. A low negative environmental impact positively affects satisfaction with the public administration of tourism.

H3. A high positive socio-cultural impact positively affects satisfaction with the public administration of tourism.

\section{Empirical Study}

Next, we present the empirical study's main characteristics, centered on the methods of information collection, the design of the measurement instrument, and the statistical techniques used in the data analysis.

\subsection{Data Collection and Research Instrument}

To test the hypotheses proposed an empirical study was done based on an electronic questionnaire given to residents in the city of Seville aged 18 years and older. The selection of the respondents was done with a snowball-type convenience sample, using emails and social networks, obtaining a total of 447 valid questionnaires after eliminated those that were incomplete or which contained systematic or inconsistent answers, as well as observations which did not fulfill the criteria suggested by Hair et al. [45] to handle lost data. The collection of information via the online questionnaire was carried out during the months of June, July, and August 2019. The description of the sample is detailed in Table 1.

Table 1. Profile of the respondents.

\begin{tabular}{lcccccc}
\hline \multirow{2}{*}{ GENDER } & Female & Male & & & \\
& $44.30 \%$ & $55.70 \%$ & & & \\
\cline { 1 - 3 } AGE & Under $\mathbf{3 1}$ & $\mathbf{3 1 - 5 0}$ & & $51-70$ & Over 70 & \\
& $14.70 \%$ & $57.90 \%$ & $34.60 \%$ & $1.02 \%$ & \\
& & & & & \\
\multirow{2}{*}{ JOB } & Student & Self-employed & Employee & Unemployed & Retired \\
& $4.30 \%$ & $26.10 \%$ & $61.10 \%$ & $7.70 \%$ & $0.90 \%$ \\
\hline
\end{tabular}

Regarding the measurement instruments used, all the constructs were measured based on 7-point Likert scales where value seven indicates the best situation possible; that is, high positive economic impact, high positive social impact, low environmental impact, and high satisfaction with the administration. All the scales are made up of indicators extracted from the theoretical review carried out, and specifically adapted to our study, centered on the resident's subjective view and not on objective impact data. With a view to maintaining an appropriate balance between the three impact dimensions (economic, environmental, and socio-cultural), each one of them is composed of the same number of indicators - eleven — some of which are extracted from the proposal elaborated by the European Commission (ETIS) [18], others from the study done by Sancho and García [20], and the rest has been prepared ad-hoc for this research, based on studies on public procurement indicators conducted by Bernal et al. [5]. The variable satisfaction with the public administration of tourism is, for its part, formed by five indicators extracted from the ETIS [12], and also measured via a 7-point Likert scale.

\subsection{Measurement Model}

As to the statistical techniques used, we opted for the variance-based approach or Partial Least Squares (PLS), utilizing the SmartPLS software version 3.2.7. All the constructs were modeled in mode A. This involves an evaluation of the measurement model based on the application of the traditional measurements of internal consistency, reliability, and validity [46]. In this line, in a first phase the factor loadings of the indicators were analyzed. These must attain the value of 0.6 for an exploratory 
research work, which implies a refining process of the scale aimed at eliminating the indicators that are not very reliable. The final scale must assure a high internal consistency, measured both through the Cronbach alpha and the composite reliability index. The results for the reliability, both individual and composite, are offered in Table 2.

Table 2. Results of the measurement model.

\begin{tabular}{|c|c|c|c|c|}
\hline & Loadings & $\begin{array}{l}\text { Cronbach } \\
\text { Alpha }\end{array}$ & $\begin{array}{l}\text { Composite } \\
\text { reliability }\end{array}$ & AVE \\
\hline Economic Impact & & 0.898 & 0.922 & 0.663 \\
\hline ** Tourism has generated employment in the city & 0.814 & & & \\
\hline *** Tourism development attracts important brands to Seville & 0.821 & & & \\
\hline ** All the economic sectors are favored by the arrival of tourists & 0.774 & & & \\
\hline ** Tourism is attracting investments for the city & 0.854 & & & \\
\hline ** Tourism has contributed to the creation of new firms & 0.855 & & & \\
\hline ** Tourism has increased the number of self-employed workers & 0.764 & & & \\
\hline Environmental Impact & & 0.924 & 0.935 & 0.618 \\
\hline ** Tourists generate a high volume of waste & 0.657 & & & \\
\hline * Tourists use too much energy & 0.777 & & & \\
\hline ** Tourists use too much water & 0.807 & & & \\
\hline * Tourists negatively affect the environment of Seville & 0.819 & & & \\
\hline ** Tourism negatively affects the Sevillian lifestyle & 0.817 & & & \\
\hline $\begin{array}{l}\text { ** Tourists have worsened the acoustic contamination (generated } \\
\text { by noise) }\end{array}$ & 0.794 & & & \\
\hline ** Tourism negatively affects traffic congestion in Seville & 0.731 & & & \\
\hline ** Tourism is degrading the city & 0.857 & & & \\
\hline *** The current tourism model is not sustainable in Seville & 0.799 & & & \\
\hline Social Impact & & 0.868 & 0.896 & 0.519 \\
\hline ** Tourism has boosted the protection of the cultural heritage & 0.670 & & & \\
\hline $\begin{array}{l}\text { ** The improvement of cultural, educational, and recreational } \\
\text { means is a consequence of tourism }\end{array}$ & 0.698 & & & \\
\hline ** Tourism has contributed to the recuperating of traditional crafts & 0.790 & & & \\
\hline${ }^{* *}$ Tourism has contributed to the recuperating of local traditions & 0.738 & & & \\
\hline $\begin{array}{l}\text { ** The educational level of the population has improved through } \\
\text { tourist contact }\end{array}$ & 0.710 & & & \\
\hline *** Tourism is stimulating local trade & 0.707 & & & \\
\hline * Tourism has boosted accessibility for disabled people in the city & 0.709 & & & \\
\hline $\begin{array}{l}\text { *** Tourism has contributed to attracting qualified workers to our } \\
\text { city }\end{array}$ & 0.738 & & & \\
\hline Satisfaction with the Public Administration of Tourism & & 0.802 & 0.862 & 0.558 \\
\hline $\begin{array}{l}{ }^{*} \text { I am satisfied with the participation and influence of the citizens } \\
\text { in the tourist planning and development of Seville }\end{array}$ & 0.621 & & & \\
\hline $\begin{array}{l}* * * \text { I am satisfied with the public administration of tourism in } \\
\text { Seville }\end{array}$ & 0.638 & & & \\
\hline${ }^{* * *}$ In general, the arrival of tourists is positive for the city & 0.801 & & & \\
\hline${ }^{*}$ I am satisfied with the tourism that the city receives & 0.804 & & & \\
\hline $\begin{array}{l}\text { ** I am satisfied with the level of development of the tourism } \\
\text { sector in the city }\end{array}$ & 0.843 & & & \\
\hline
\end{tabular}

The average variance extracted (AVE) is applied to attest the convergent validity of the Mode A constructs. In our model, all the constructs and dimensions satisfy this criterion as their AVEs surpass the level of 0.5 (Table 2). To accept the discriminant validity, which indicates that each construct differs from the other constructs, two means are used: The squared correlation of the construct must not exceed the value of the AVE [47] and the HTMT index (Heterotrait-Monotrait Ratio) [48]. All the values of the matrix are below 0.85 [49] (Kline, 2010), and also the confidence intervals for the HTMT do not contain the value 1 [48], so the discriminant validity is accepted (Table 3). 
Table 3. Measurement Model. Discriminant Validity.

\begin{tabular}{lcccccccc}
\hline & \multicolumn{3}{c}{ Fornell-Larcker Criterion } & \multicolumn{5}{c}{ Heterotrait-Monotrait Ratio HTMT } \\
\hline & ECON & ENV & SAT & SC & ECON & ENV & SAT & SC \\
ECON & 0.814 & & & & & & & \\
ENV & 0.524 & 0.786 & & & 0.541 & & & \\
SAT & 0.779 & 0.541 & 0.747 & & 0.680 & 0.555 & \\
SC & 0.762 & 0.436 & 0.682 & 0.721 & 0.843 & 0.455 & 0.791 & \\
\hline
\end{tabular}

Note: ECON: Economic Impact; ENV: Environmental Impact; SAT: Satisfaction with the Public Administration of Tourism;SC: Social Impact.

\subsection{Structural Model}

Having concluded the analysis of the measurement model, we analyzed the structural model. Firstly, the possible existence of multicollinearity between the antecedent variables of the endogenous construct was tested. According to Hair et al. [50], there exist signs of multicollinearity when the VIF indicator is above 5. In the structural model proposed problems of multicollinearity do not exist. After this, a Bootstrapping (5000 samples) was done. This provides both the $t$ values and the confidence intervals which allow the evaluation of the statistical significance of the relations. The empirical evidence reveals that there exists a significant relation between the three impact dimensions analyzed (economic, environmental, and social) and the satisfaction with the public administration of tourism, so hypotheses H1, H2, and H3 are accepted. Table 4 shows the direct effects included in our research model.

Table 4. Results of the structural model.

\begin{tabular}{|c|c|c|c|c|c|c|}
\hline & Path & P Values & T statistics & $\begin{array}{l}\text { Confidence } \\
\text { Interval }\end{array}$ & f2 & Supported \\
\hline ECON $->$ SAT & 0.538 & $0.000^{* * *}$ & 7.863 & {$[0.395 ; 0.666]$} & 0.306 & Yes \\
\hline ENV $->$ SAT & 0.173 & $0.000^{* * * *}$ & 3.617 & {$[0.086 ; 0.271]$} & 0.061 & Yes \\
\hline SC $->$ SAT & 0.197 & $0.003^{* *}$ & 2.985 & {$[0.071 ; 0.328]$} & 0.046 & Yes \\
\hline
\end{tabular}

The application of blindfolding enables evaluating the predictive importance of the constructs. When carrying out blindfolding procedures, all the Q2 values are above zero, which backs the predictive relevance for the endogenous constructs (Table 5). Values higher than $0.25(0.325)$ depict medium predictive accuracy of the PLS path model [29].

Table 5. Effects on the endogenous variables.

\begin{tabular}{lccccc}
\hline & $\mathbf{R}^{2}$ & $\mathbf{Q}^{2}$ & Direct effect & Correlations & $\begin{array}{c}\text { Variance } \\
\text { explained }\end{array}$ \\
\hline Satisfaction with tourism & 0.647 & 0.325 & & & \\
H1: Positive Economic Impact & & & 0.538 & 0.779 & $41.87 \%$ \\
H2: Negative Environmental Impact & & & 0.173 & 0.541 & $9.35 \%$ \\
H3: Positive Socio-cultural Impact & & & 0.197 & 0.682 & $13.46 \%$ \\
\hline
\end{tabular}

The coefficient of determination (R2) is also examined to evaluate the explanatory power for the endogenous constructs and indicates the quantity of variance of a construct which is explained by the predictive variables of this endogenous construct in the model [51]. Therefore, in the model proposed the Economic Impact explains $41.87 \%$ of the satisfaction with the public administration of tourism, the environmental impact $9.35 \%$ of it, and the socio-cultural impact explains $13.46 \%$ of this satisfaction (Table 5). 
All indicator's Q2-predict values are positive and comparing the RMSE values from the PLS-SEM analysis with the naïve LM benchmark (Table 6), we find that the PLS-SEM analysis produces lower prediction errors for all the indicators. Therefore, high predictive power was achieved [52].

Table 6. Effects on the endogenous variables.

\begin{tabular}{lcc}
\hline & $\mathbf{Q}^{\mathbf{2}}$-predict & RMSE (PLSsem-LM) \\
\hline Satisfaction with tourism & 0.617 & \\
SAT03 & 0.483 & -0.028 \\
SAT01 & 0.179 & -0.036 \\
SAT05 & 0.443 & -0.053 \\
SAT02 & 0.116 & -0.073 \\
SAT04 & 0.473 & -0.064 \\
\hline
\end{tabular}

\section{Discussion}

The results obtained in this study confirm that a high perceived economic impact, a low environmental impact, and a high socio-cultural impact have a positive and significant effect on satisfaction with the public administration of tourism.

The positive influence of the economic impact supports hypothesis $\mathrm{H} 1$ as it explains a variance of $41.87 \%$. Therefore, it is stated that the perception of a high economic impact can be translated into a clear improvement in the satisfaction with the public administration of tourism. This result is in line with previous studies concerning the need to include economic impacts in the assessment of this public administration $[9,18,20,24]$. However, our study is a pioneer in assessing the economic impacts from a subjective perspective, based on the opinion of the residents in the locality analyzed. In this way, if the residents perceive that tourism really contributes to economic development and the improvement of the citizens' standard of living, they will be more satisfied with the public administration and therefore more inclined to tolerate the discomforts that coexistence with tourists can generate.

As to the socio-cultural impact, as hypothesis $\mathrm{H} 3$ postulates this also shows a significant positive influence on satisfaction with the public administration of tourism, explaining $13.46 \%$ of the satisfaction. This result confirms that the social impacts of tourism are important in confirming the residents' satisfaction. They value not only the economic effects on the locality but also the impacts on its society and culture. In this, many studies are in accordance, but this paper is a pioneer in revealing that the residents really value these impacts, even more than those that are environmental.

Finally, the perceived environmental impact also has a significant influence on satisfaction with the public administration of tourism, so hypothesis $\mathrm{H} 2$ is supported as well and explains $9.35 \%$ of the variance of the satisfaction with the public administration of tourism. In this sense, we can therefore state that if the residents perceive a low environmental impact in the city due to the tourism activity, they will be satisfied with the public administration of tourism. This result is also innovative, as it uses measurements of the residents' subjective perception, though the environmental impact is considered relevant in all the previous studies analyzed $[9,18,20]$. We must highlight the fact that the residents accord this dimension less important for satisfaction with the administration of tourism than the rest of the impacts. This is perhaps a reflection of a scant development of environmental awareness.

\section{Conclusions}

This research sought to find out the effect that economic, social, and environmental impacts perceived by the residents in a tourism destination have on satisfaction with the public administration of tourism. The citizens, under the perspective addressed, have a specific perception about the positive and negative effects that the tourism activity has on them. Phenomena of tourismphobia and situations of rejection of the public administration may arise when this perception is negative. This can have very adverse effects on the coexistence in the city and its image as a tourism destination. This is why to know the residents' perception about the economic, social, and environmental repercussion of tourism 
can be useful for the public managers of tourism, who make great efforts of public procurement which is reflected, for example, in the search for major events or new air connections for the city.

The attraction of sustainable tourism tends to be one of the priorities of public managers. However, the positive return on the investment necessary to attract the target of suitable tourism for the city is not recuperated directly, rather it is through the benefits which are obtained from the tourists that this public investment is justified. Nonetheless, we know that these visitors do not only produce economic benefits, there is also the inconvenience derived from the environmental damage which they can cause and, on the other hand, they have an influence on the city's socio-cultural field. Therefore, including indicators which are not only economic, but also social and environmental, as Bernal et al. [5] postulate, must be considered a key strategic variable, which enables the political actors to know and understand to what extent the attraction of tourists is going to generate positive perceptions among the residents. These indicators, as has been revealed in this study, must not be only objective, but also subjective, as it will be the citizens' perceptions which determine their level of acceptation of tourism policies for their destination and, therefore, their readiness to welcome the tourists that the locality receives.

We must highlight the great importance that residents accord to the positive economic impact which tourism produces in the city. The perception of the citizens is that their city is clearly seen to benefit from the generation of employment, the creation of new firms, and the attraction of investments, which improves their satisfaction with the public administration of tourism.

The importance of the socio-cultural impact is also especially significant. This leads the citizens to be concerned by the effect that tourism has on the on the protection of the cultural heritage, employment among disadvantaged groups, and the improvement of the cultural, educational, and recreational means caused by the development of tourism.

Although it has a significant influence, the environmental impact is in the last position in terms of its relative importance for the residents' satisfaction. This must serve as a clear call to the public managers that they have to increase their endeavor for the citizens to perceive that the environmental effort produces low environmental impacts and, therefore, there is an improvement of the quality of life in the city.

Various limitations prevent the generalization of the study's results. A first limitation of our study is that it has only been carried out on a sample of residents in the city of Seville. The residents of this city in the south of Spain have their own cultural and social characteristics. In addition, this city hosts a large number of tourists and a great diversity of large events throughout the year. Another limitation comes from the non-longitudinal nature of the study. Nevertheless, the theoretical foundations set out support the causal relationships of the research's hypotheses.

As a future line of research, we propose to carry out an intercultural study to measure the effect that different cultures have on residents' perceptions of tourism impacts. We also propose to conduct the study in cities with lower tourist density. In addition, future research could examine the role of different variables, such as tourist density, the city's brand, the city's image, or the city's reputation as possible moderators. Finally, we consider the study of gentrification and tourismphobia as possible consequences of residents' perceptions of the negative impacts that tourists have on their cities.

Author Contributions: Conceptualization, M.-Á.R.-C.; data curation, M.-E.S.d.R.-V.; formal analysis, C.J.R.-R; investigation, M.-Á.R.-C.; methodology, C.J.R.-R; software, C.J.R.-R; writing-original draft, M.-E.S.d.R.-V.; writing-review and editing, M.-Á.R.-C.

Funding: This research has been financed by UPV/EHU, LantegiBatuak, and GEAccounting, project number US17_24.

Conflicts of Interest: The authors declare no conflict of interest. The funders had no role in the design of the study; in the collection, analyses, or interpretation of data; in the writing of the manuscript, or in the decision to publish the results. 


\section{References}

1. European Commission Communication from the Commission EUROPE 2020. In A Strategy for Smart, Sustainable and Inclusive Growth; Commission of the European Communities: Brussels, Belgium, 2010.

2. Gutiérrez Ponce, H.; Nevado Gil, M.T.; Pache Durán, M. La contratación pública responsable. Diseño de indicadores de medición. CIRIEC España Revista Economía Pública Social Cooperativa 2019, 96, 253-280. [CrossRef]

3. Domenech, J.R.; Salas, J. Medición del Impacto y Avance de la Compra Pública Sustentable en América Latina y el Caribe; Red Interamericana de Compras Gubernamentales (RICG): Washinton, DC, USA, 2015.

4. CONAMA. GT-6. Contratación y compra pública sostenible e innovadora; Congreso Nacional del Medioambiente (CONAMA), Madrid, Spain. 2016. Available online: http://www.conama.org/conama/ download/files/conama2016/GTs\%202016/6_final.pdf (accessed on 11 November 2019).

5. Bernal, R.; San-Jose, L.; Retolaza, J.L. Improvement Actions for a More Social and Sustainable Public Procurement: A Delphi Analysis. Sustainability 2019, 11, 4069. [CrossRef]

6. European Commission. Buying Social. A Guide to Taking Account of Social Considerations in Public Procurement. Available online: https://op.europa.eu/en/publication-detail/-/publication/cb70c481-0e294040-9be2-c408cddf081f/language-en (accessed on 11 November 2019).

7. Gónzalez García, J. Sostenibilidad Social y Ambiental en la Directiva 2014/24/CE, de Contratación Pública. Rev. Española Derecho Eur. 2015, 14, 13-42.

8. Plan de Contratación Pública Ecológica. Available online: https://www.miteco.gob.es/es/ministerio/planesestrategias/plan-de-contratacion-publica-ecologica/ (accessed on 28 October 2019).

9. Palomeque, F.L.; Torres-Delgado, A.; Urgell, X.F.; Miracle, D.S. Sustainable management of tourist destinations: The implementation of a system of indicators of tourism in the destinations of the province of Barcelona. Bol. Asoc. Geogr. Esp. 2018, 2018, 428-461.

10. Budeanu, A.; Miller, G.; Moscardo, G.; Ooi, C.S. Sustainable tourism, progress, challenges and opportunities: An introduction. J. Clean. Prod. 2016, 111, 285-294. [CrossRef]

11. Tourism, Trade and the WTO: A Joint Communication from UNWTO, WTO, ITC and WTTC World Tourism Organization UNWTO. Available online: http://www2.unwto.org/press-release/2018-10-08/tourism-tradeand-wto-joint-communication-unwto-wto-itc-and-wttc (accessed on 28 October 2019).

12. World Tourism Organization. Sustainable Tourism for Development Guidebook-Enhancing Capacities for Sustainable Tourism for Development in Developing Countries; UNWTO: Madrid, Spain, 2013.

13. World Tourism Organization. Indicators of Sustainable Development for Tourism Destinations; World Tourism Organization: Madrid, Spain, 2004; ISBN 9284407265.

14. Miller, G. The development of indicators for sustainable tourism: Results of a Delphi survey of tourism researchers. Tour. Manag. 2001, 22, 351-362. [CrossRef]

15. Asmelash, A.G.; Kumar, S. Assessing progress of tourism sustainability: Developing and validating sustainability indicators. Tour. Manag. 2019, 71, 67-83. [CrossRef]

16. Melgarejo, A.M.; Sariego López, I.; Ávila Bercial, R. La planificación y la gestión como herramientas de desarrollo de los destinos turísticos. Turydes Rev. Tur. Desarro. Local Sosten. 2018, 12, 25.

17. Inglezakis, V.J.; Zorpas, A.A. Environmental indicators. Sustain. Behind Sustain. 2014, 29, 17-33.

18. European Commission. The European Tourism Indicator System; Publications Office of the European Union: Luxembourg, Luxembourg, 2016; ISBN 9789279552496.

19. Definición. Organización Mundial del Turismo OMT. Available online: http://www2.unwto.org/es/content/ definicion (accessed on 28 October 2019).

20. Sancho Perez, A.; Garcia, G.M. What does an indicator indicate? Comparative analysis in tourist destinations. Tour. Anal. Mag. 2006, 2, 69-85.

21. Díaz Armas, R.J.; Gutiérrez Taño, D. La actitud del residente en el destino turístico de Tenerife: Evaluación y tendencia. PASOS Rev. Tur. Patrim. Cult. 2010, 8, 431-444. [CrossRef]

22. Gursoy, D.; Jurowski, C.; Uysal, M. Resident attitudes. Ann. Tour. Res. 2002, 29, 79-105. [CrossRef]

23. Singh, R.K.; Murty, H.R.; Gupta, S.K.; Dikshit, A.K. An overview of sustainability assessment methodologies. Ecol. Indic. 2012, 15, 281-299. [CrossRef]

24. Cordero Fernández, J.C. Propuesta de un sistema de indicadores de sostenibilidad turística para destinos urbanos. ARA J. Tour. Res. Rev. Investig. Tur. 2017, 7, 41-51. 
25. Vehbi, O.B. A Model for Assessing the Level of Tourism Impacts and Sustainability of Coa stal Cities. In Strategies for Tourism Industry: Micro and Macro Perspectives; Books on Demand: Norderstedt, Germany, 2012; pp. 99-114.

26. Liu, Z. Sustainable tourism development: A critique. J. Sustain. Tour. 2003, 11, 459-475. [CrossRef]

27. Canalejo, A.M.C.; Sánchez-Cañizares, S.; Roldán, L.S. Desarrollo turístico en Cabo Verde. Perfil y percepción del residente en Sao Nicolau. Rev. Responsab. Soc. Empres. 2018, 28, 77-102.

28. Harrill, R. Residents' attitudes toward tourism development: A literature review with implications for tourism planning. J. Plan. Lit. 2004, 18, 251-266. [CrossRef]

29. Del, D. Percepción de los Residentes; Estudio de Caso en la Provincia de Zamora: Zamora, Spain, 2016; pp. 158-162.

30. Gursoy, D.; Ouyang, Z.; Nunkoo, R.; Wei, W. Residents' impact perceptions of and attitudes towards tourism development: A meta-analysis. J. Hosp. Mark. Manag. 2019, 28, 306-333. [CrossRef]

31. Monterrubio, J.C. Residents ' Perception of Tourism: A Critical Theoretical and Methodological Review. Cienc. Ergo Sum 2008, 15, 35-44.

32. Taño, D.G.; Armas, R.J.D.; Rodríguez, F.G. Contexto del alquiler vacacional en los espacios turísticos: Satisfacción de la demanda y actitud del residente. In La Residencialización de las Áreas Turísticas de Canarias; Santa Cruz de Tenerife: Promotur Turismo Canarias/Universidad Internacional Menéndez y Pelayo; Promotur Turismo Canarias, S.A.: Canarias, Spain, 2016; pp. 163-188.

33. Ko, D.W.; Stewart, W.P. A structural equation model of residents' attitudes for tourism development. Tour. Manag. 2002, 23, 521-530. [CrossRef]

34. Sánchez, A.V.; Mejía, M.Á.P.; Bueno, N.P. Desarrollo del turismo y percepción de la comunidad local: Factores determinantes de su actitud hacia un mayor desarrollo turístico. In Proceedings of the Empresa Global y Mercados Locales: XXI Congreso Anual AEDEM, Universidad Rey Juan Carlos, Madrid, Spain, 6-8 June 2007; Escuela Superior de Gestión Comercial y Marketing(ESIC): Madrid, Spain, 2007; p. 24.

35. Marzo-Navarro, M.; Pedraja-Iglesias, M.; Vinzón, L. Sustainability indicators of rural tourism from the perspective of the residents. Tour. Geogr. 2015, 17, 586-602. [CrossRef]

36. Gee, C.Y.; Fayos Solá, E.; World Tourism Organization. WTO Education Network. International Tourism: A Global Perspective; World Tourism Organization: Madrid, Spain, 1997; ISBN 9789284402311.

37. Communication from the Commission to the European Parliament, the Council, the European Economic and Social Committee and the Committee of the Regions Public procurement for a Better Environment $\{$ SEC(2008) 2124\} \{SEC(2008) 2125\} \{SEC(2008) 2126\}—Publications Office of the EU. Available online: https://op.europa.eu/en/publication-detail/-/publication/cf756423-a925-4dce-bc1e-f0a20cd6db26/ language-en/format-PDF/source-107336514 (accessed on 28 October 2019).

38. EUR-Lex-32014L0024-EN-EUR-Lex. Available online: https://eur-lex.europa.eu/eli/dir/2014/24/oj (accessed on 28 October 2019).

39. Lesmes, S.; Álvarez de Eulate, L. Guía de Contratación Pública Socialmente Responsable Compra Pública Responsible; Red de Economía Alternativa y Solidaria Sarea: Bilbao, Spain, 2014; pp. 3-10.

40. WTO Publications 2002; ISBN 9789284410910. Available online: https://www.e-unwto.org/doi/book/10.18111/ 9789284410910 (accessed on 11 November 2019).

41. Pimentel, D.; Santos, D.O. El nivel de satisfacción de los residentes con el turismo en Canet d'En Berenguer, Cullera y Oliva. ARA J. Tour. Res. 2019, 9, 47-62.

42. Covarrubias Ramírez, R.; Vargas Vásquez, A.; Rodríguez Herrera, I.M. Satisfacción De Residentes Con El Desarrollo De La Actividad Turística En Los Pueblos Mágicos De México: Un Indicador De Competitividad. Casos De Comala En Colima Y De Real De Asientos En Aguascalientes. Gestión Turística 2010, 14, $33-54$. [CrossRef]

43. Rátz, T. Residents' Perceptions of the Socio-Cultural Impacts of Tourism at Lake Balaton, Hungary. In Tourism and Sustainable Community Development; Routledge: London, UK, 2002; pp. 54-65.

44. Rasoolimanesh, S.M.; Ali, F.; Jaafar, M. Modeling residents' perceptions of tourism development: Linear versus non-linear models. J. Destin. Mark. Manag. 2018, 10, 1-9. [CrossRef]

45. Hair, J.F. A Primer on Partial Least Squares Structural Equations Modeling (PLS-SEM); Sage publications: Thousand Oaks, CA, USA, 2014; ISBN 9781452217444.

46. Henseler, J.; Ringle, C.M.; Sarstedt, M. Testing measurement invariance of composites using partial least squares. Int. Mark. Rev. 2016, 33, 405-431. [CrossRef] 
47. Fornell, C.; Larcker, D.F. Evaluating structural equation models with unobservable variables and measurement error. J. Mark. Res. 1981, 18, 39-50. [CrossRef]

48. Henseler, J.; Ringle, C.M.; Sarstedt, M. A new criterion for assessing discriminant validity in variance-based structural equation modeling. J. Acad. Mark. Sci. 2015, 43, 115-135. [CrossRef]

49. Kline, R.B. Principles and Practice of Structural Equation Modeling; Guilford Press: New York, NY, USA, 2010; ISBN 1606238787.

50. Hair, J.F.; Henseler, J.; Dijkstra, T.; Sarstedt, M.; Ringle, C.; Diamantopoulos, A.; Straub, D.; Ketchen, D.; Gtm, H.; Calantone, R. Common Beliefs and Reality about Partial Least Squares: Comments on Rönkkö and Evermann. Organ. Res. Methods 2014, 17, 182-209.

51. Chin, W.W. How to write up and report PLS analyses. In Handbook of Partial Least Squares; Springer: Berlin/Heidelberg, Germany, 2010; pp. 655-690, ISBN 3540328254.

52. Shmueli, G.; Sarstedt, M.; Hair, J.F.; Cheah, J.H.; Ting, H.; Vaithilingam, S.; Ringle, C.M. Predictive model assessment in PLS-SEM: Guidelines for using PLSpredict. Eur. J. Mark. 2019. [CrossRef]

(C) 2019 by the authors. Licensee MDPI, Basel, Switzerland. This article is an open access article distributed under the terms and conditions of the Creative Commons Attribution (CC BY) license (http://creativecommons.org/licenses/by/4.0/). 